\title{
Benefits of an intervention programme with racket sports in primary school students. Racket sports in elementary school students
}

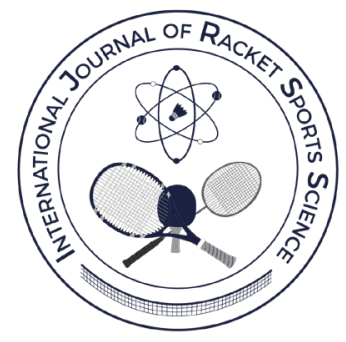

Emilio J. Ruiz-Malagón, ${ }^{1,2}$; Gabriel Delgado-García, ${ }^{(1,2}$; Elena López-Gutiérrez; Félix Zurita-Ortega ${ }^{\circledR}$; Víctor M. Soto-Hermoso ${ }^{(1,2}$

1 Department of Physical Education and Sports, Faculty of Physical Activity and Sports Sciences, University of Granada, Spain

2 Sport and Health Research Institute (iMUDS), University of Granada, Spain

3 Department of English Language, Faculty of Philosophy and Letters, University of Granada, Spain

4 Department of Didactics of Musical, Plastic and Corporal Expression of the Faculty of Educational Sciences, University of Granada, Spain

Received: 22-01-2020

Accepted: $27-10-2020$

\begin{abstract}
This experimental study is aimed at implementing a one-month racket sports programme within a sample of students aged 9 to 13 years in order to analyze its motivational climate effects during physical education lessons in a primary school context. The intervention programme was carried out on 40 of the 285 participants, the rest of the sample were used for descriptive purposes. The subjects participated voluntarily and were randomly assigned to one of two groups: control $(n=20)$ and experimental $(n=20)$. The programme consisted of eight sessions of different racket sports (tennis, paddle, badminton and table tennis). Motivational climate was extracted from the "Questionnaire of Motivational Climate Perceived in Sport" (PMCSQ-2). PMCSQ-2 reported two dimensions, task and ego. Regarding the results obtained, no changes were found in the control group. However, in the experimental group there was a significant increase $(P<0.05)$ in the orientation towards the task $(3.22$ vs 4.36), leading to the detriment of the ego orientation ( $3.4 \mathrm{vs} 2.25$ ). Thus, racket sports activity seem to be adequate to change motivational orientation towards the task, which has been reported to increase intrinsic motivation and to reduce stress and anxiety in physical education lessons.
\end{abstract}

Keywords: Motivational climate; PMCSQ-2; tennis; badminton; paddle.

Correspondence author: Emilio J. Ruiz-Malagón, emiliorm@correo.ugr.es

Cite this article as:

Ruiz-Malagón, E. J., Delgado-García, G., Loud-Gutiérrez, E., Zurita-Ortega, F., \& Soto-Hermoso, V. M. (2020). Benefits of an intervention program with racket sports in elementary school students. Racket sports in elementary school students. International Journal of Racket Sports Science, 2(1), 9-17.

This is an open access article under the CC BY license (http://creativecommons.org/licenses/by/4.0/). 


\section{INTRODUCTION}

Physical Education content as a school subject is often discussed in public and political debates (Jones and Green, 2015). In recent years, legislative reforms have been made in European education systems (Jones and Green, 2015; Ruin, 2015; Kirk, 2005). Comprehensive educational reforms have changed physical education, but the programmes with racket sports are still rare in primary schools and there are no specific studies of its practical implementation despite its multiple proven benefits (Hoffmann, Brixius, and Vogt, 2018). Racket sports have overwhelming advantages for children (Farrow and Reid, 2016; Jiménez, 2009), since they contribute to the development of perceptivemotor skills, control one's own body and promote learning and health education values. They are also beneficial to the development of tolerance in order to respect individual differences (sex, race, social class and political or religious beliefs), always encouraging an "equal opportunities" education (Jiménez, 2009). According to Guioti, Toledo, and Scaglia (2014), racket sports are an ideal tool for the integration of students with mild intellectual disabilities, favoring their normalization, socialization and non-discrimination by their peers. Similarly, Faber, Bustin, Oosterveld, Elferink-Gemser, and Nijhuis-Van der Sanden (2016) state that anyone can practice racket sports regardless of their physical and intellectual qualities. In addition, racket sports are ideal for improving laterality during the primary education stage (Llanos, 2015) and according to Oja, Kelly, Pedisic, Titze, Bauman, Foster, Hamer, Hillsdon and Stamatakis (2016) they reduce the risk of suffering from a heart attack or cardiovascular disease by $47 \%$. Referring to the reports mentioned above, racket sports should be considered a basic part of the physical education curriculum, supporting the development of motor skills and conditional aspects for children in primary schools (Hoffmann, Brixius, and Vogt, 2018). Based on these findings our study focused on racket sports implementation in primary physical education.

Motivation can be defined as: 'the set of social variables, contextual, performance and persistence in the activity' (Moreno, Durán, and De la Lastra, 2016). Furthermore, motivation is a crucial factor for the practice of physical exercise and sport, since the athlete's orientation and behavior have been shown to significantly influence the athlete's start, maintenance and abandonment of sports practice (Sandoval, Caracuel, and Ceballos, 2014). The motivation is also useful to optimize sports performance (Sandoval, Caracuel, and Ceballos, 2014). Weinberg and Gould, (1996) collect some actions that will help to raise the motivation of students such as encouraging cooperation and success, using positive reinforcements, establishing achievable challenges and working around the areas of interest to students. The theoretical constructs of motivational climates
(Ames, 1992) and goal orientations (Nicholls, 1989) are essential in understanding children's experiences with sports since both emphasize the importance of motivation in the process of performing regular physical activity. All of the aforementioned information, they are discussed below.

The theory of goal perspectives (Ames, 1992; Nicholls, 1984, 1989) attaches great importance to the role played by cognitive processes associated with motivational responses. Success and failure are considered to be psychological states that can only be identified when based on the goal of the subject's behavior (Sandoval, Caracuel and Ceballos, 2014). Nicholls (1984) defends the idea that the subjects in achievement situations act under two goal perspectives (task and ego involved). Nicholls (1984) also states that task and ego involved relate to the way in which subjects define success, failure and judge their level of competence. When a person is task involved, they will show behaviors, affections and cognitions that will lead to maximum motivation, independently of one's perception of ability. Nicholls (1984) suggests that a task-involved goal will bring effort, low anxiety, high fun and intrinsic interest in the activity. Instead, considering subjects with egoinvolved, if the perception of the ability is high, an adaptive model of achievement will be developed but, on the contrary, if the perceived ability is low, there will be a little adaptive model of achievement. Subsequently, ego involved is characterized by reduced effort, high anxiety and decreased intrinsic motivation and persistence (Nicholls, 1984). It proved that the state of goal involvement of the individual appears by variations in the degree of orientation to the ego and task, in addition to the variations of the motivational climate in which the behavior takes place (Balaguer, Guivernau, Duda, and Crespo, 1997). Most of the research conducted on this topic has been carried out in the school environment (aged 9 to 16 years) (McLaren, Newland, Eys, and Newton 2017; Liukkonen, Barkoukis, Watt, and Jaakkola, 2010). There is evidence to show that the motivational climate varies if it is a team or individual sport (racket sports), being individual sports more likely to foster the ego involved (Tello, Martínez, Núñez, and Calvo, 2010).

As the motivational climate decisively influences the initiation and maintenance of physical activity (Sandoval, Caracuel, and Ceballos, 2014) and the need for interventions where importance is given to personal development and effort (González-Valero, ZuritaOrtega, and Martínez -Martínez, 2017), this intervention is proposed, where the teacher will be in charge of creating a motivational climate based on the process and personal benefit (González-Valero, Zurita-Ortega, and Martínez-Martínez, 2017). In addition, a gap in the literature is detected when analysing how a racket sports programme can influence motivational climate since it is a type of sports practice infrequently used during the primary stage (Hoffmann, Brixius, and Vogt, 2018). 
The principal aim of the study is to implement a one-month racket sports programme, along with other interventions with racket sports (Faber, Pion, and Nijhuis-Van der Sanden, 2019; Tsetseli, Malliou, Zetou, Michalopoulou, and Kambas, 2010), in a sample of students aged 9 to 13 years to analyze its effect on motivational climate during physical education classes in elementary school. Also, as a secondary objective of the present research, it compared the obtained levels of motivation in relation to the sport practice outside school, racket sports practice, type of racket sport and gender. It is hypothesized that our intervention with racket sports will reduce the ego involved and increase the task involved in a sample of Spanish students during physical education classes.

\section{METHODOLOGY \\ Participants}

For this study, data were collected from 285 participants, of which $54.7 \%(n=156)$ were boys and $45.3 \%(n=129)$ girls. They were students attending different schools in the city of Granada with an age range from 9 to 13 years old. The intervention programme was carried out with only 40 of the 285 participants because it could only be done in one of the schools selected. Participants voluntarily performed the study and were randomly assigned to one of two groups: control $(n=20)$ and experimental $(n=20)$. The data collected from the rest of them was used to describe the motivational climate based on the gender, sport practice outside the school, the practice of racket sport and type. All tests completed by the participants had the approval of the Ethics Committee of the University of Granada. Additionally, this study complied with the ethical standards of the World Medical Association Declaration of Helsinki signed in 2013.

\section{Procedures}

For the collection of data, an official letter was first delivered from the University of Granada to the different schools; more precisely, from the Department of Musical Didactics, Plastic and Corporal Expression in the Faculty of Educational Sciences. With this official letter and with the aim of developing the present research study, permission from the schools was requested in order to legally gather data. Parents were also asked to sign a written informed consent. The data collection process lasted two sessions: one for the "pre-test" and the other one for the "posttest". It took forty-five minutes for each participant to complete the questionnaires. Study participants collectively conducted the questionnaires in the classroom during a school day. By means of a record sheet, information from gender, practice of sport outside school, practice of racket sport and type is collected.
The motivational climate of the participants was analyzed through the Questionnaire of Motivational Climate Perceived in Sport (PMCSQ-2) developed by Newton and Duda (1993); it presents evidence of its validity and reliability on male and female school students (aged 9 to 16 years), in different sports such as soccer, racket sports, athletics, basketball, volleyball and dance (Balaguer, Guivernau, Duda, and Crespo, 1997; Newton, Duda, and Yin 2000; Hancox, Quested, Viladrich, and Duda, 2015; McLaren, Newland, Eys, and Newton 2017). In the present study, the Spanish version was applied (Gónzalez-Cutre, Sicilia, and Moreno, 2008) since the sample used was made up of Spanish children. Moreover, the Spanish version of the questionnaire has been equally used in other research studies (Coterón-Lopez, Franco, PérezTejero, and Sampedro, 2013), to check the effect of motivational climate in children. This consists of 33 items with a Likert scale of 5 options where 1 means "totally disagree" and 5 "strongly agree". The Spanish version of the PMCSQ-2 reported two dimensions: task involved (mean of items 1, 4, 5, 8, 10, 11, 14, 16, 19, 20, $21,25,28,30,31,32$ and 33 ) and ego involved (mean of items $2,3,6,7,9,12,13,15,17,18,22,23,24,26,27$ and 29).

In addition, after collecting the sample of the "pretest", a racket sports programme was carried out in a primary school located in Granada during the hours of physical education classes, which lasted eight sessions of racket sports practice (two $45 \mathrm{~min}$ sessions per week) and one introductory theory session (1 hour) to explain the dynamics of the programme to the participants. The sessions were divided into a $10 \mathrm{~min}$ warm-up, $30 \mathrm{~min}$ for the main part and $5 \mathrm{~min}$ to return to calm. The duration of the programme was 5 weeks, like other similar interventions with racket sports in schools (Faber, Pion, and Nijhuis-Van der Sanden, 2019; Tsetseli, Malliou, Zetou, Michalopoulou, and Kambas, 2010). The racket sports chosen for the programme were based on the study of Hoffmann, Brixius, and Vogt (2018) who conclude that the most practical sports in primary school are badminton and tennis. The other selected sports were paddle and beach tennis with a wooden racket, since we had to adapt to the possibilities of the school hosting the intervention. Two sessions were held for each of the aforementioned racket sports.

The development of the sessions was fully adapted to the methodology called "modified technical model". According to Duaigues and Fuentes-Guerra (2010), this methodology is the most frequently used in teaching racket sports during the initiation stage, which is characterized for maintaining a central position of the teacher; considering tasks, the choice of them without opposition and utilization of positive reinforcements and corrections takes place. Based on the model of Duaigues and Fuentes-Guerra (2010) the most valuable aspect during the intervention will be the progression of teaching in technical aspects. 


\section{Variables}

Task and Ego involved: dimensions extracted from the questionnaire PMCSQ-2.

Gender: through the dichotomous option of "male" or "female".

Sports practice outside school: sport practice was registered, by means of the dichotomous option of whether or not it was practiced outside school, using a record sheet where participants were encouraged to choose between the option 'yes', as long as the student did the physical activity outside the school, or 'no', if they did not practice it.

Racket sport practice: racket sport practice was obtained through the dichotomous option of whether or not it was practiced, using a registration form.

Type of racket sport: type of racket sport was divided into four options: I) tennis, II) paddle tennis, III) table tennis and IV) badminton.

\section{Statistical analysis}

To carry out the statistical analysis and the execution of tables and figures, the IBM SPSS Statistics Data Editor Version 20 programme was used. To check the normality of the variables, the KolmogorovSmirnov normality test was administered. One Way ANOVA and the post hoc analysis of Bonferroni was used as tool to compare the means of task and ego involvement varying on gender, sports practice outside school, racket sport practice and type of racket sport. Additionally, One Way ANOVA and analysis of Bonferroni was also used to compare the means of task and ego involved between the pre and post-test in the control group and the experimental group. The level of significance used was $p<0.05$. The internal consistency of the study is demonstrated by Cronbach's alpha $(\alpha=0.809)$. The effect size was calculated using the freeware Psychometric (Lenhard and Lenhard, 2016). D-Cohen was used as follow: 0.2 to 0.4 small effect, 0.5 to 0.7 medium effect and $>0.8$ strong effect (Cohen, 1988).

\section{RESULTS}

The total sample $(n=285)$ was composed of $54.7 \%$ of boys and $45.3 \%$ of girls. The analysis of the frequency in the practice of out-of-school sports shows that $22.8 \%$ of the sample did not practice any sport outside school, while $77.2 \%$ did so. With respect to the frequency in the practice of racket sports, $77.5 \%$ of the sample did not practice any racket sport, whereas a $22.5 \%$ did. In relation to the type of racket sport practiced by each individual, $77.5 \%$ practiced none, while $11.9 \%$ practiced paddle, $8.1 \%$ tennis, $1.8 \%$ table tennis and $0.7 \%$ badminton. The average values (mean \pm standard deviation) obtained in the task orientation was $3.87 \pm 0.72$ and for ego orientation $2.66 \pm 0.88$.

Table 1 presents the relation between motivational climate and gender. No statistically significant differences were found among task orientation or ego orientation ( $p>0.05)$. The ANOVA, used to compare the motivational climate in relation to the practice of extra-curricular sport, revealed significant differences in task orientation $(p=0.016)$, since practitioners are more oriented towards this option. The effect size was small (Table 2). Statistically significant differences were again found between the motivational climate and the practice of racket sport, specifically in the ego orientation. Those participants who did racket sports were also more oriented towards ego orientation, resulting in the effect size being small (Table 2).

Table 2 shows the relation between task and ego involved with the type of racket sport practiced but there are no significant differences.

Table 1.

Comparison of task and ego involved based on gender, sports practice outside school and racket sports practice of all the participants.

\begin{tabular}{|c|c|c|c|c|c|}
\hline & $\mathrm{N}$ & & & & \\
\hline & & Male (156) & Female (129) & $p$ & d Cohen \\
\hline Task & & $3.91 \pm 0.722$ & $3.82 \pm 0.724$ & 0.262 & 0.189 \\
\hline \multirow[t]{3}{*}{ Ego } & 285 & $2.64 \pm 0.856$ & $2.69 \pm 0.902$ & 0.645 & 0.048 \\
\hline & & \multicolumn{2}{|c|}{ Extracurricular sport (N) } & & \\
\hline & & Yes (220) & No(65) & $\mathrm{p}$ & d Cohen \\
\hline Task & & $3.93 \pm 0.714$ & $3.68 \pm 0.727$ & $0.016^{*}$ & 0.347 \\
\hline \multirow[t]{3}{*}{ Ego } & 285 & $2.69 \pm 0.877$ & $2.55 \pm 0.872$ & 0.232 & 0.251 \\
\hline & & \multicolumn{2}{|c|}{ Practice of racket sport (N) } & & \\
\hline & & Practising(64) & Nonpractising(221) & $p$ & d Cohen \\
\hline Task & & $3.86 \pm 0.703$ & $3.87 \pm 0.730$ & 0.853 & 0.105 \\
\hline Ego & 285 & $2.89 \pm 0.911$ & $2.59 \pm 0.857$ & $0.016^{*}$ & 0.339 \\
\hline
\end{tabular}

${ }^{*} \mathrm{P}<0.05 ;{ }^{* *} \mathrm{p}<0.01 ;{ }^{* * *} \mathrm{p}<0.001 ;{ }^{*} \mathrm{~d}$ Cohen: small effect size (0.2 to 0.4$)$; intermediate effect (0.5 to 0.7$)$; large effect (>0.8); ${ }^{*}$ Means \pm standard deviation 
Regarding the analysis of the intervention with racket sports, $(n=40$; control group $=20$ and experimental group $=20$ ) relevant comparisons are displayed in Figure 1. It compares the average statistical values of task orientation and ego orientation that were obtained in the "pre-test" and the "post-test" within the control group and the experimental group. No significant differences ( $p>0.05$ ) were found, neither in the task, nor ego in the control group. In the experimental group after the intervention, task orientation was equal to 4.36 ( 0.61 ) and ego orientation to 2.25 (0.58). Statistically significant differences were found $(p<0.001)$ between the value of the task orientation obtained in the pre-test and the post-test, being the effect size strong $(d=2.23)$. There were also significant differences $(p<0.013)$ between the value of the Ego orientation in the pre-test and post-test being the effect size strong again $(d=2.01)$ (Cohen, 1988).

Table 2.

Task and ego involved depending on the type of racket sport practiced by all the participants.

\begin{tabular}{lccc}
\hline Motivational climate & Sport (N) & Means \pm SD & P \\
\hline & None(221) & $3.87 \pm 0.73$ & \\
Task involved & Pennis(23) & $3.89 \pm 0.63$ & \\
& Taddle(34) & $3.85 \pm 0.75$ & 0.915 \\
& Badminton(2) & $4.14 \pm 0.87$ & \\
\hline & None (221) & $2.59 \pm 0.86$ & \\
& Tennis(23) & $2.74 \pm 0.99$ & \\
Ego involved & Paddle(34) & $2.98 \pm 0.87$ & 0.125 \\
& Table tennis(5) & $3.08 \pm 1.05$ & \\
& Badminton(2) & $2.65 \pm 0.57$ & \\
\hline
\end{tabular}

*SD: Standard deviation; * $p<0.05 ;{ }^{* *} p<0.01 ;{ }^{* * *} p<0.001$

\section{DISCUSSION}

In the present investigation, conducted on a sample of 285 elementary school students, it was initially found that approximately three quarters of them practiced extra-curricular physical activity, this result coinciding with the previous study carried out by Castro, Zurita, Martínez, Chacón, and Espejo (2016). This high percentage in extra-curricular sports practice that we found was probably due to the great investment made in sport facilities and, therefore, in infrastructures, during recent years; this helped access for young people. The results also indicate that approximately one fifth of the sample who play sports outside school choose a racket sport, as shown in the studies of Molla (2007) and García (2006), since primary school students have a preference for other sport disciplines such as football, handball or basketball (Luengo Vaquero, 2007). Focusing on the type of racket sport practiced, the results obtained demonstrate that the practice of paddle predominates, coinciding with its explosion in the last decade and closely followed by tennis. These results support previous research by Garcia (2006) and Molla (2007), that showed that the most practiced racket sports are paddle and tennis in this order.

When evaluating the average statistical values of the motivational climate, it is verified that significantly higher scores were achieved in the task climate than in the ego climate; this data coincides with that obtained by Méndez-Giménez, Fernández-Río, Cechini, and González (2013) and González-Cutre, Sicilia, and Moreno (2011) in his studies with students of the same age as our research. These results indicate that the participants of the sample give more importance to the process than to the result. This favours the involvement in physical education lessons and the adherence to physical activity practice as importance is given to personal growth and effort causing a reduction of stress, anxiety and an increase in intrinsic motivation of the students (Méndez-Giménez, Fernández-Río, Cechini, and González, 2013).

With respect to the motivational climate, its relation with different socio-demographic variables such as gender, sport practice outside school, racket sports practice and the type of racket, are also present. The results show significant differences in the case of the task orientation, with their average values being higher among those who practice sport outside school. In the same way, Mora, Cruz, and Sousa (2013) pointed out that this could happen due to a greater adherence to the students' sports practice. There were also significant differences among participants who practice racket sports, since higher ego orientation values were obtained, probably because most racket sports are practiced individually or in pairs and, therefore, they do not encourage social relationships as opposed to team sports (Balaguer, Guivernau, Duda, and Crespo, 1997). While no differences were found in the relation of motivational climate with gender, it was not the case in the study carried out by Florez, Salguero, Molinero, and Marquez (2011), who found higher ego orientation in boys' than in girls, possibly caused by a higher age range in their sample, which has been shown to affect the motivational climate (Méndez-Giménez, García-Romero, and Cechini, 2018). Méndez-Giménez, García-Romero and Cechini, (2018), demonstrated that the age range from 13 to 14 years shows a greater sensitivity to variations in the motivational climate and perhaps, for this reason, our results do not coincide with those of Florez, Salguero, Molinero, and Marquez (2011). With regard to the type of racket sport practiced, no significant differences were observed. We have not found any reference that could explain this issue. 
Although the effects of an intervention with racket sports in a sub-sample were analyzed, there were no changes in the control group or in task or ego involved. However, in the experimental group the task involved values significantly increased, whereas the ego involved values significantly decreased. This demonstrates, as we hypothesized, that racket sports in an educational environment will bring effort, low anxiety, high fun and intrinsic interest to the activity. Our results could be extended to other countries since the intrinsic motivation in sport has been tested in different European countries (France, Greece, Norway and England) giving similar results (Viladrich et al., 2013). Other sports disciplines like soccer or handball tend to promote the task involved because they are team sports and it is demonstrated that they favor this dimension (Balaguer, Guivernau, Duda, and Crespo, 1997; Gómez-López, Granero-Gallegos, BaenaExtremera, and Abraldes, 2014; Mфllerløkken, Lorås, and Pedersen, 2017). Therefore, introducing racket sports into school would be an appropriate way to use individual sports during physical education classes in elementary education. Besides this, our results support the recommendation of Iglesias (2016) who states that using racket sports in primary education favours the acquisition of basic skills such as hygiene and health values, as well as tolerance; he also uses physical education and sports as a means of promoting personal and social growth. The chosen methodology (modified technical model) turned sports, just as Duaigues and Fuentes-Guerra, (2010) explained in their study. In this respect, the increases in the task climate after the intervention with racket sports also guarantee the success with the proposed out to be appropriate for the initiation into racket

methodology since this is a demonstration that improves the intrinsic motivation of students during physical education lessons.

Regarding the strengths of this study, this is a pre-post experimental research in which the effects on the motivational climate of a racket sports programme were evaluated; this is a novelty due to the aforementioned gap in the literature and given the need for interventions based on the process and personal benefit of the students. Despite careful consideration, the present study comprises a few limitations. A racket sports programme of just 5 weeks duration was held because students must meet the annual physical education curriculum. A longer programme could show better effects on the motivational climate of the students. For future research, the aim is to increase the sample size and the duration of the programme, in addition to verifying how long the effects on the motivational climate are maintained.

\section{CONCLUSIONS}

In conclusion, our intention was to check the effects of a racket sports programme on the motivational climate of primary school students, contributing to the dissemination of knowledge in this area. It is evident how our introduction to the racket sports has significantly increased the orientation towards the task, leading to the detriment of the ego involved. Racket sports seem to be adequate for changing motivational orientation towards the task which has been reported to increase intrinsic motivation in physical education. This finding can be useful for all physical education teachers who are willing to improve the motivational climate in their classrooms.

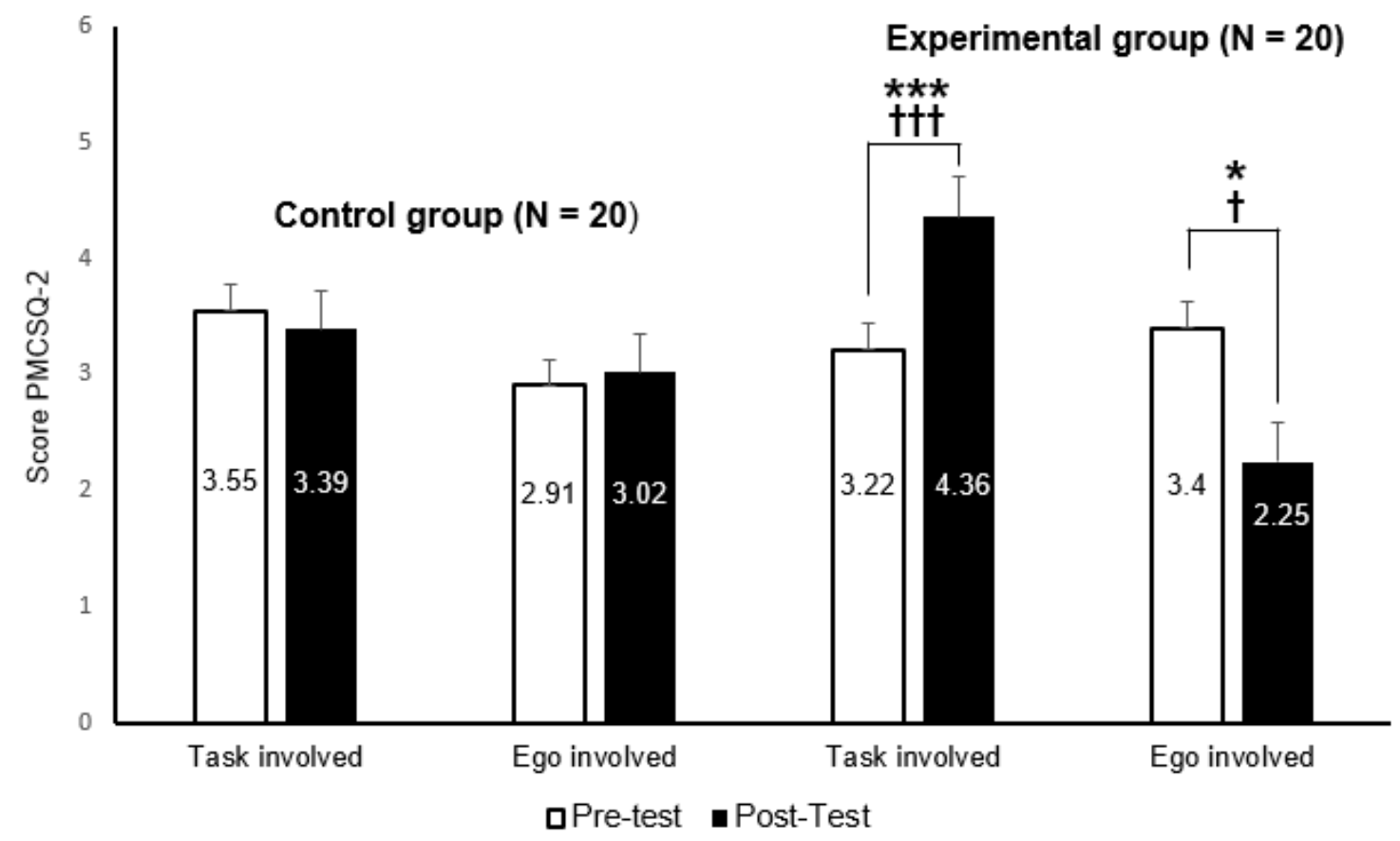

Figure 1. Comparison of the motivational climate before and after its implementation in the control group and the experimental group. ${ }^{*} \mathrm{p}<0.05 ;{ }^{* *} \mathrm{p}<0.01 ;{ }^{* * *} \mathrm{p}<0.001 ; \dagger$ small effect size (0.2 to 0.4 ); †† intermediate effect (0.5 to 0.7 ); ††† large effect $(>0.8)$. 


\section{ACKNOWLEDGMENTS}

This study did not receive financial support. No potential conflict of interest was reported by the authors. The authors would like to thank all those students who participated in this research as well as to the teacher who facilitated the study.

\section{REFERENCES}

Ames, C. (1992). Achievement goals, motivational climate and motivational processes. In G.C. Roberts (Ed.), Motivation in Sport and Exercise (pp. 161-176). Champaign, IL: Human Kinetics.

Balaguer, I., Guivernau, M., Duda, J., \& Crespo, M. (1997). Análisis de la validez de constructo y de la validez predictiva del cuestionario de clima motivacional percibido en el deporte (PMCSQ-2) con tenistas españoles de competición [Analysis of the validity of the construct and the predictive validity of the questionnaire of motivational climate perceived in sport (PMCSQ-2) with Spanish competition tennis players]. Revista de Psicología del Deporte, 6(1), 4158.

Castro-Sánchez, M., Zurita-Ortega, F., MartinezMartinez, A., Chacón-Cuberos, R., \& Espejo-Garcés, T. (2016). Clima motivacional de los adolescentes y su relación con el género, la práctica de actividad física, la modalidad deportiva, la práctica deportiva federada y la actividad fisica familiar [Motivational climate of adolescents and their relationship with gender, the practice of physical activity, sports, federated sports practice and family physical activity]. Revista Internacional de Ciencias del Deporte, 12(45), 262-277. http://dx.doi.org/10.5232/ ricyde2016.04504

Cohen, J. (1988). Statistical power analysis for the behavioral sciences (2. Auflage). Hillsdale, NJ: Erlbaum. http://dx.doi.org/10.4324/9780203771587

Coterón-López, J., Franco, E., Pérez-Tejero, J. y Sampedro, J. (2013). Clima motivacional, competencia percibida, compromiso y ansiedad en Educación Física. Diferencias en función de la obligatoriedad de la enseñanza. Revista de Psicología del Deporte, 22(1), 151-157.

Duaigues, J. C., \& Fuentes-Guerra, F. J. G. (2010). Metodología de enseñanza utilizada en la enseñanza del tenis durante la etapa de iniciación. [Teaching methodology used in the teaching of tennis during the initiation stage]. RETOS, Nuevas tendencias en Educación Física, Deporte y Recreación, 18, 60-65.

Faber, I., Bustin, P., Oosterveld, F., Elferink-Gemser, M., \& Nijhuis-Van Der Sanden, M. (2016). Assessing personal talent determinants in young racquet sport players: a systematic review. Journal of Sports Sciences, 34 (5), 395-410. http://dx.doi.org/10.1080/ 02640414.2015.1061201
Faber, I., Pion, J., \& Nijhuis-Van der Sanden, M. (2019). The benefits of the 5-week Table Stars @school program as part of physical education in primary schools - A pilot intervention study. International Journal of Racket Sports Science, 1(1), 3-15.

Farrow, F., \& Reid, M. (2016). Scaling tennis racquets during PE in Primary School to enhance motor skill acquisition. Research Quarterly for Exercise and Sport, 87 (4), 414-420. https://doi.org/10.1080/0270 1367.2016.1216653

Florez, J.A., Salguero, A., Molinero, O., \& Márquez, S. (2011). Relación de la habilidad física percibida y el clima motivacional percibido en estudiantes de secundaria, colombianos [Relationship of perceived physical ability and perceived motivational climate in high school students, Colombians]. Psychología Avances de la Disciplina, 5(2), 69-79. http://dx.doi. org/10.21500/19002386.1134

García, M. (2006). Veinticinco años de análisis del comportamiento deportivo de la población española (1980-2005) [Twenty-five years of analysis of the sporting behavior of the Spanish population (1980-2005)]. Revista Internacional de Sociología, 64(44), 15.

Gómez-López, M., Granero-Gallegos, A., BaenaExtremera, A., \& Abraldes, J. A. (2014). Goal orientation effects on elite handball players motivation and motivational climate. ProcediaSocial and Behavioral Sciences, 132, 434-440.

González-Cutre, D., Sicilia, A., \& Moreno J.A. (2008). Modelo cognitivo-social de la motivación de logro en educación física [Cognitive-social model of achievement motivation in physical education]. Psicothema, 20(4), 642-651.

González-Valero, G., Zurita-Ortega, F., \& MartínezMartínez, A. (2017). Panorama motivacional y de actividad fisica en estudiantes: una revisión sistemática. ESHPA, Education, Sport, Health and Physical Activity. 1(1), 41-58.

Guioti, T., Toledo, E., \& Scaglia, A.J. (2014). Racquet sports for mild intellectual disabilities: a proposal based on the pedagogy of sport. Revista Brasileira de Educaçao Especial, 20(3), 357-370. http://dx.doi. org/10.1590/S1413-65382014000300004

Hancox, J. E., Quested, E., Viladrich, C., \& Duda, J. L. (2015). Examination of the internal structure of the behavioural regulation in sport questionnaire among dancers. International Journal of Sport and Exercise Psychology, 13(4), 382-397.

Hoffmann, D., Brixius, K., \& Vogt, T. (2018). Racket sports teaching implementations in physical education-a status quo analysis of German primary schools. Journal of Physical Education and Sport, 18(2), 867873. 
Iglesias, A. (2016). The Core Competencies Through Table Tennis. Technical Journal of School Sport Physical Education and Psychomotricity, 2(2), 268287. http://dx.doi.org/10.17979/sportis.2016.2.2.1476

Jiménez, L. (2009). Juegos de pala y raqueta en la Escuela Primaria [Shovel and racket games in the Primary School]. Revista Pedagógica de Educación Física ADAL,19, 24-29.

Jones, L., \& Green, K. (2015). Who teaches primary physical education?: Change and transformation through the eyes of subject leaders. Sport, Education and Society, 3(2), 1-13.

Kirk, D. (2005). Physical education, youth sport and lifelong participation: The importance of early learning experiences. European Physical Education Review, 11(3), 239-255.

Lenhard, W., \& Lenhard, A. (2016). Calculation of Effect Sizes. Dettelbach (Germany): Psychometrica. Retrieved from https://www.psychometrica.de/ effect_size.html.

Liukkonen, J., Barkoukis, V., Watt, A., \& Jaakkola, T. (2010). Motivational climate and students' emotional experiences and effort in physical education. The Journal of Educational Research, 103(5), 295-308.

Llanos, D.A., \& Castiblanco, F.C. (2015). Propuesta Didáctica para Mejorar la Lateralidad a través de la Introducción a los Deportes con Raqueta en los Niños del Curso 407 del Colegio Francisco José De Caldas Sede B [Didactic Proposal to Improve Laterality through the Introduction to Racket Sports in Children of Course 407 of the Francisco José De Caldas School Headquarters B]. Tesis doctoral: Universidad de Bogotá.

Luengo Vaquero, C. (2007). Actividad físico-deportiva extraescolar en alumnos de primaria [Physicalathletic activity out of school in primary school students]. Revista Internacional de Medicina y Ciencias de la Actividad Física y el Deporte, 7(27) 174-184

McLaren, C. D., Newland, A., Eys, M., \& Newton, M. (2017). Peer-initiated motivational climate and group cohesion in youth sport. Journal of Applied Sport Psychology, 29(1), 88-100.

Méndez-Giménez, A., Fernández-Río, J., Cechini, J.A., \& González, C. (2013). Perfiles motivacionales y sus consecuencias en educación física. Un estudio complementario de metas al logro $2 \times 2$ y autodeterminación [Motivational profiles and their consequences in physical education. A complementary study of 2x2 achievement goals and self-determination]. Revista de Psicología del Deporte, 22(1), 29-38.

Méndez-Giménez, A., García-Romero, C., \& Cecchini, J.A. (2018). Metas de logro $3 \times 2$, amistad y afecto en educación física: diferencias edad-sexo. Revista Internacional de Medicina y Ciencias de la Actividad Física y el Deporte, 18 (72) 637-653.

Mollá, M. (2007). La influencia de las actividades extraescolares en los hábitos deportivos de los escolares [La influencia de las actividades extraescolares en los hábitos deportivos de los escolares]. Revista Internacional de Medicina y Ciencias de la Actividad Física y el Deporte, 7(27), 241-252.

Møllerlфkken, N. E., Lorås, H., \& Pedersen, A. V. (2017). A comparison of players' and coaches' perceptions of the coach-created motivational climate within youth soccer teams. Frontiers in psychology, 8, 109.

Mora, Á., Cruz, J., \& Sousa, C. (2013). Cómo mejorar el clima motivacional y los estilos de comunicación en el ámbito de la Educación Física y el deporte. Infancia y Aprendizaje, 36(1), 91-103.

Moreno, P., Durán, F., \& De la Lastra, A. (2016). Motivación en ciencias del deporte [Motivation in sports science]. Revista de Educación, Motricidad e Investigación, 4, 55-78.

Newton, M. L., \& Duda, J. L. (1993). The Perceived Motivational Climate in Sport Questionnaire: Construct and Predictive Utility. Journal of Sport and Exercise Psychology,15, S56.

Newton, M., Duda, J.L., \& Yin, Z. (2000). Examination of the psychometric properties of the Perceived Motivational Climate in Sport Questionnaire-2 in a sample of female athletes. Journal of Sports Sciences, 18(4), 275-290. http://dx.doi. org/10.1080/026404100365018

Nicholls, J. (1984). Achievement motivation: Conceptions of ability, subjective experience, task choice, and performance. Psychological Review, 91, 328-346.

Nicholls, J.G. (1989). Competence and accomplishment: A psychology of achievement motivation. Cambridge, MA: Harvard University Press.

Oja, P., Kelly, P., Pedisic, Z., Titze, S., Bauman, A., Foster, C., Hamer, M., Hillsdon, M., \& Stamatakis, E. (2016). Associations of specific types of sports and exercise with all-cause and cardiovascular-disease mortality: a cohort study of 80306 British adult. British Journal Sports Medicine, 51(10), 812. http:/ / dx.doi.org/10.1136/bjsports-2016-096822

Ruin, S. (2015). Körperbilder in Schulsportkonzepten: Eine körpersoziologische Untersuchung. (Thesis). Köln: Deutsche Sporthochschule.

Sandoval, J. R. G., Caracuel, J. C., \& Ceballos, O. (2014). Motivación Y Ejercicio Físico Deportivo: Una Añeja Relación. Revista Internacional de Ciencias Sociales y Humanidades, SOCIOTAM, 24(1), 71-88. 
Tello, F. P. H., Martínez, L. N., Núñez, M. L., \& Calvo, T. G. (2010). A structural model of goal orientation in sports: Personal and contextual variables. The Spanish Journal of Psychology, 13(1), 257-266.

Tsetseli, M., Malliou, V., Zetou, E., Michalopoulou, M., \& Kambas, A. (2010). The effect of coordination training program on the development of tennis service technique. Biology of Exercise, 6(1), 29-36.

Viladrich, C., Appleton, P. R., Quested, E., Duda, J. L., Alcaraz, S., Heuzé, J. P., Fabra, P., Samdal, O., Ommundsen, Y., Hill, A. P., Zourbanos, N., \& Ntoumanis, N. (2013). Measurement invariance of the Behavioural Regulation in Sport Questionnaire when completed by young athletes across five European countries. International Journal of Sport and Exercise Psychology, 11(4), 384-394.

Weinberg, R., \& Gould, D. (1996). Fundamentos de Psicología del deporte y el ejercicio [Fundamentals of sports psychology and exercise]. Barcelona: Ariel. 